\title{
Evaluation of Pro-Inflammatory Cytokines Expression in Mouse Splenocytes After Co-Incubation with the Biofield Energy Treated Formulation: Impact of the Trivedi Effect ${ }^{\circledR}$
}

\author{
Mahendra Kumar Trivedi ${ }^{1}$, Alice Branton ${ }^{1}$, Dahryn Trivedi ${ }^{1}$, Gopal Nayak ${ }^{1}$, Michael Peter Ellis ${ }^{1}$, \\ James Jeffery Peoples ${ }^{1}$, James Joseph Meuer ${ }^{1}$, Johanne Dodon ${ }^{1}$, John Lawrence Griffin ${ }^{1}$, \\ John Suzuki ${ }^{1}$, Joseph Michael Foty ${ }^{1}$, Judy Weber ${ }^{1}$, Julia Grace McCammon ${ }^{1}$, Karen Brynes Allen ${ }^{1}$, \\ Kathryn Regina Sweas $^{1}$, Lezley Jo-Anne Wright ${ }^{1}$, Lisa A. Knoll ${ }^{1}$, Madeline E. Michaels ${ }^{1}$, \\ Margaret Kweya Wahl' ${ }^{1}$, Mark E. Stutheit ${ }^{1}$, Michelle Barnard ${ }^{1}$, Muriel Mae Ranger ${ }^{1}$, \\ Paromvong Sinbandhit ${ }^{1}$, V. J. Kris Elig ${ }^{1}$, Sambhu Charan Mondal ${ }^{2}$, Snehasis Jana ${ }^{2,}$, \\ ${ }^{1}$ Trivedi Global, Inc., Henderson, USA \\ ${ }^{2}$ Trivedi Science Research Laboratory Pvt. Ltd., Bhopal, Madhya Pradesh, India
}

Email address:

publication@trivedieffect.com (S. Jana)

${ }^{*}$ Corresponding author

To cite this article:

Mahendra Kumar Trivedi, Alice Branton, Dahryn Trivedi, Gopal Nayak, Michael Peter Ellis, James Jeffery Peoples, James Joseph Meuer, Johanne Dodon, John Lawrence Griffin, John Suzuki, Joseph Michael Foty, Judy Weber, Julia Grace McCammon, Karen Brynes Allen, Kathryn Regina Sweas, Lezley Jo-Anne Wright, Lisa A. Knoll, Madeline E. Michaels, Margaret Kweya Wahl, Mark E. Stutheit, Michelle Barnard, Muriel Mae Ranger, Paromvong Sinbandhit, V. J. Kris Elig, Sambhu Charan Mondal, Snehasis Jana. Evaluation of ProInflammatory Cytokines Expression in Mouse Splenocytes After Co-Incubation with the Biofield Energy Treated Formulation: Impact of the Trivedi Effect $^{\circledR}$. International Journal of Biomedical Science and Engineering. Vol. 4, No. 5, 2016, pp. 40-49. doi: $10.11648 /$ j.ijbse.20160405.11

Received: November 29, 2016; Accepted: December 8, 2016; Published: December 29, 2016

\begin{abstract}
With the increasing popularity of herbomineral preparations in healthcare, a new proprietary herbomineral formulation was formulated with ashwagandha root extract and minerals viz. zinc, magnesium, and selenium. The aim of the study was to evaluate the immunomodulatory potential of Biofield Energy Healing (The Trivedi Effect ${ }^{\circledR}$ ) on the herbomineral test formulation using mice splenocytes. The test formulation was divided into two parts. One part was the control without the Biofield Treatment. The other part was labelled the Biofield Treated sample, which received the Biofield Energy Healing Treatment remotely from twenty renowned Biofield Energy Healers. The splenocyte cells were exposed with the test formulation at ranges of 0.00001053 to $10.53 \mu \mathrm{g} / \mathrm{mL}$ for cell viability by MTT assay, with cell viability ranging from $77.50 \%$ to $176.52 \%$. TNF- $\alpha$ was significantly inhibited by $15.88 \%, 15.28 \%, 12.30 \%, 12.60 \%$, and $22.72 \%$ at $0.00001053,0.001053$, $0.1053,1.053$, and $10.53 \mu \mathrm{g} / \mathrm{mL}$, respectively in the Biofield Treated test formulation compared to the vehicle control (VC). TNF- $\alpha$ was significantly reduced by $2.33 \%$ and $8.35 \%$ at 1.053 and $10.53 \mu \mathrm{g} / \mathrm{mL}$, respectively compared to the untreated test formulation. IL- $1 \beta$ was significantly reduced by $30.81 \%, 27.36 \%, 23.92 \%, 18.40 \%, 11.27 \%$, and $21.16 \%$ at 0.00001053 , $0.0001053,0.001053,0.01053,0.1053$, and $1.053 \mu \mathrm{g} / \mathrm{mL}$, respectively in the Biofield Treated test formulation compared to the VC. IL-1 $\beta$ was significantly reduced by $48.63 \%(p \leq 0.001)$ and $15.28 \%$ at 0.00001053 and $0.0001053 \mu \mathrm{g} / \mathrm{mL}$, respectively in the Biofield Treated test formulation compared to the untreated test formulation. MIP- $1 \alpha$ expression was inhibited by the Biofield Treated test formulation and showed immunosuppressive activity at $0.01053,0.1053,1.053$, and $10.53 \mu \mathrm{g} / \mathrm{mL}$ by $22.33 \%, 16.25 \%, 15.58 \%$, and $21.83 \%$, respectively compared to the VC. The Biofield Treated test formulation significantly reduced the MIP- $1 \alpha$ expression by $13.27 \%$ and $15.67 \%(p<0.05)$ at 0.01053 and $10.53 \mu \mathrm{g} / \mathrm{mL}$, respectively compared to the untreated test formulation. The results showed the expression of IFN- $\gamma$ was significantly reduced by $33.45 \%, 25.38 \%, 37.15 \%$, $27.74 \%, 32.44 \%, 23.03 \%$, and $44.21 \%$ at $0.00001053,0.0001053,0.001053,0.01053,0.1053,1.053$, and $10.53 \mu \mathrm{g} / \mathrm{mL}$, respectively in the Biofield Treated test formulation compared to the VC. Further, the IFN- $\gamma$ level was significantly decreased by $19.02 \%$ at $10.53 \mu \mathrm{g} / \mathrm{mL}$ in the Biofield Treated test formulation compared to the untreated test formulation. Overall, the
\end{abstract}


results demonstrate that The Trivedi Effect ${ }^{\circledR}$ Biofield Energy Healing (TEBEH) significantly enhanced the anti-inflammatory and immunomodulatory properties of the treated formulation, and may also be useful in organ transplants, anti-aging, and stress management by improving overall health and quality of life.

Keywords: Biofield Energy Healing Treatment, Biofield Energy Healers, The Trivedi Effect ${ }^{\circledR}$, Inflammation, Immunomodulation, Splenocytes, MIP-1 $\alpha$, IL- $1 \beta$, TNF- $\alpha$, IFN- $\gamma$

\section{Introduction}

Herbomineral formulations have always been a major target for scientific research due to their significant immunomodulatory potential. Plant products and their extracts are used in both allopathic health care as well as complementary and alternative health care in order to improve overall health and the immune system [1, 2]. However, much attention has been focused on discovering herbal products with immunomodulatory activity along with low toxicity and better bioavailability [3]. Many scientific studies have identified the immunomodulatory properties of medicinal plants, which can be further potentiated with the addition of some minerals that regulate the immune cells. These types of formulations are commonly defined as herbomineral formulations and are the major target for pharmaceutical companies as phytopharmaceutical products or as dietary supplements. Based on the literature, a new proprietary herbomineral formulation was formulated with a combination of the herbal root extract ashwagandha (Withania somnifera) and three minerals viz. zinc, magnesium, and selenium. All the ingredients of the formulation in this present study possess important activities such as immune-modulatory, anti-inflammatory, antioxidant, anti-infective, and anti-viral properties [4-7]. Ashwagandha has been reported to have an effect on biological activity mainly due to the presence of withanolides, and it is used as an herbal medicine in alternative and complementary therapies [8, 9]. Apart from its common attributes such as antibacterial, immunomodulatory and antitumor effects, many clinical and preclinical data have been available with respect to its immunomodulatory impact [4, 10]. Minerals such as selenium, zinc, and magnesium have been shown to have significant importance in modulating the immune system, and their synergistic impact has been well-defined [5]. Scientific research has documented that in the presence of minerals, herbal medicines have been found to exhibit a high level of phagocytic index and improved antibody titer [11]. These formulations can be used for better therapeutic effects in immune compromised patients affected with cardiovascular diseases, age and stress related diseases, cancer, and autoimmune disorders. Along with herbomineral formulations, the Biofield Energy Healers in this study have used energy medicine (Biofield Energy Healing Treatments) as a complementary and alternative approach to study the impact of Biofield Energy Treatments on the specified herbomineral formulation for its immunomodulatory potential with respect to the pro-inflammatory cytokines in splenocyte cells isolated from mice.
According to scientific studies and clinical trials, Biofield Energy Treatments have been reported to have significant outcome in terms of the enhanced immune function of cervical cancer patients with therapeutic touch [12] and massage therapy [13], etc. The National Center of Complementary and Integrative Health (NCCIH) has recognized and accepted Biofield Energy Healing as a Complementary and Alternative Medicine (CAM) health care approach in addition to other therapies, medicines and practices such as yoga, deep breathing, meditation, natural products, Qi Gong, mindfulness, massage, traditional Chinese herbs and medicines, Ayurvedic medicine, chiropractic/osteopathic manipulation, acupuncture, Tai Chi, acupressure, healing touch, special diets, naturopathy, progressive relaxation, homeopathy, guided imagery, relaxation techniques, hypnotherapy, movement therapy, pilates, essential oils, aromatherapy, cranial sacral therapy, rolfing structural integration, applied prayer (as is common in all religions, like Buddhism, Hinduism, Christianity and Judaism), and Reiki. To this day, Biofield Energy Healing has had significant impact in the transformation of living organisms and nonliving materials including metals, ceramics, polymers, chemicals, and pharmaceutical compounds. Human Biofield Energy has subtle energy that has the capacity to work in an effective manner [14]. Reports show that Complementary and Alternative Medicine (CAM) therapies have been practiced worldwide with clinical benefits in different health disease profiles [15]. This energy can be harnessed and transmitted by individuals into living organisms and non-living things via the process of Biofield Energy Healing. Biofield Energy Treatments (The Trivedi Effect ${ }^{\circledR}$ ) have been extensively studied with significant outcomes in many scientific fields such as cancer science $[16,17]$, altering microbial characteristics and features including changing the microbial sensitivity of pathogenic microbes in microbiology [18-21], genetics [22, 23], altered physical and chemical compounds in pharmaceutics [24-27], improved the overall productivity, quality and yield of crops and plants in agricultural science [28-31], and in materials science where The Trivedi Effect ${ }^{\circledR}$ has demonstrated its ability to alter the structural, thermal and physical properties of metals, polymers, chemicals and ceramics [32-35]. The authors of this study sought to evaluate the impact of Biofield Energy Treatment (The Trivedi Effect ${ }^{\circledR}$ ) on the given herbomineral formulation, which might improve its immunomodulatory function in an in vitro cellular model with mice splenocyte cells. 


\section{Materials and Methods}

\subsection{Chemicals and Reagent}

Lipopolysaccharide (LPS), 3-(4, 5-diamethyl-2-thiazolyl) 2, 5 diphenyl-2 H-tetrazolium) (MTT), Roswell Park Memorial Institute (RPMI-1640), L-glutamine, penicillin, streptomycin, 4-(2-hydroxyethyl)-1-piperazineethanesulfonic acid (HEPES), 2- mercaptoethanol, concanavalin A (Con-A), rapamycin, $\mathrm{NaHCO}_{3}$, and EDTA were purchased from Sigma Chemical Corp. (St. Louis, MO), a subsidiary of SigmaAldrich Corporation. ELISA (enzyme-link immunosorbent assay) assay kits for all cytokines tumor necrosis factor alpha $(\mathrm{TNF}-\alpha)$, macrophage inflammatory protein-1 $\alpha$ (MIP-1 $\alpha$ ), and interleukin-1 beta (IL-1 $\beta$ ) were purchased from R\&D Systems, USA. Fetal bovine serum (FBS) was purchased from GIBCO, USA. Ashwagandha (Withania somnifera) root extract powder ( $\geq 5 \%$ of total withanolides) was procured from Sanat Products Ltd., India. Zinc chloride and magnesium (II) gluconate hydrate were procured from Tokyo Chemical Industry Co., Ltd. (TCI), Japan. Sodium selenate was procured from Alfa Aesar, USA. All other chemicals used were of analytical grade available in India.

\subsection{Test Formulation and Reference Standard}

The test formulation contained four ingredients: ashwagandha root powder extract, zinc chloride, sodium selenite, and magnesium gluconate. LPS was used as an inflammatory stimulant, while Con-A and rapamycin were used as reference standards (the positive control) for immunostimulatory and immunosuppressive action, respectively in splenocytes assay.

\subsection{Experimental Animal}

C57BL/6 male mice ( 8 weeks old, 22 gm body weight) were purchased from Vivo Bio Tech Ltd., Hyderabad, India and acclimatized for one week prior to the experiments. The mice were maintained under controlled conditions with a temperature of $22 \pm 3^{\circ} \mathrm{C}$, humidity of $30 \%$ to $70 \%$ and a 12 hour light/12-hour dark cycle and laboratory rodent diet and drinking tap water were provided ad libitum. All the procedures were in strict accordance with the Guide for the Care and Use of Laboratory Animals published by the US National Institutes of Health (NIH). The approval of the Institutional Animal Ethics Committee (IAEC) was obtained prior to carrying out the animal experiment.

\subsection{Biofield Energy Healing Strategies}

The herbomineral formulation was divided into two parts. One part of the test formulation did not receive any sort of treatment and was defined as the control group, while the Biofield Energy Treatment was given to the other part of the herbomineral formulation, which was defined as the treated formulation group. The Biofield Energy Treatment was provided by a group of twenty Biofield Energy (The Trivedi Effect ${ }^{\mathbb{B}}$ ) Healers, thirteen of which were remotely located in the U. S. A., five in Canada, and two in Australia. The test formulation was located in Dabur Research Foundation near New Delhi in Ghaziabad, India. This Biofield Energy Treatment was administered for 5 minutes through the Healers' unique Energy Transmission process remotely to the test formulation, which was kept under standard laboratory conditions. None of the Biofield Energy Healers in this study visited the laboratory in person, nor had any contact with the herbomineral samples. Similarly, the control sample was kept under the same laboratory conditions and was subjected to "sham" healers for five minutes. The sham healers did not have any knowledge about the Biofield Energy Treatment. After that, the Biofield Energy treated and untreated test formulations were kept in similar sealed conditions and used for the in vitro study on splenocyte cells for cytokines estimation.

\subsection{Experimental Design}

The experimental study was divided into 7 groups. Group 1 comprised of the splenocyte cells without LPS and was denoted as the negative control. Group 2 served as a stimulant group that included cells with LPS. Group 3 included the splenocyte cells with LPS along with the vehicle $(0.005 \%$ DMSO) and was denoted as the vehicle control. Groups 4 and 5 were defined as the positive control, which included cells with Con-A $(0.5 \mu \mathrm{g} / \mathrm{mL})$ and rapamycin $(1 \mathrm{nM}$ and $10 \mathrm{nM})$, respectively. Groups 6 and 7 were denoted as the test item groups that included splenocyte cells with LPS along with the untreated and Biofield Treated test formulations, respectively, at concentrations 0.00001053 to $10.53 \mu \mathrm{g} / \mathrm{mL}$. After 48 hours of incubation, supernatants were analyzed for the secreted levels of TNF- $\alpha$, MIP- $1 \alpha$, and IL- $1 \beta$ using ELISA as per the manufacturer's instructions. Concentrations were determined in triplicate wells of each sample.

\subsection{Isolation of Mouse Splenocytes}

C57BL/6 male mice were sacrificed and their spleens were aseptically removed and grounded by passing them through a sterile plastic strainer under aseptic conditions. After the cells were centrifuged twice at $1000 \mathrm{~g}$ for 5 minutes, erythrocytes were lysed by a lysis buffer $\left(0.15 \mathrm{M} \mathrm{NH}_{4} \mathrm{Cl}, 0.01 \mathrm{M}\right.$ $\mathrm{NaHCO}_{3}$, and $0.1 \mathrm{mM}$ EDTA, pH 7.4) and then the cell pellets were washed twice with the RPMI-1640 medium. Further, the cells were resuspended in the complete RPMI1640 medium (RPMI 1640 medium plus $10 \%$ fetal bovine serum, $2 \mathrm{mM}$ glutamine, $100 \mathrm{IU} / \mathrm{mL}$ of penicillin and streptomycin, $15 \mathrm{mM}$ HEPES and $50 \mathrm{mM}$ 2mercaptoethanol). The cell counts were performed using a hemocytometer and cell viability was determined using the trypan-blue dye exclusion technique with the results showing $\geq 95 \%$ of viable cells. The cells were cultured in 96-well tissue culture plates with $0.2 \times 10^{6}$ cells per well. They were incubated at $37^{\circ} \mathrm{C}$ in a humidified atmosphere of $5 \% \mathrm{CO}_{2}$ for the indicated period [36].

\subsection{Cell Culture and Test Formulation Treatment}

Splenocyte $\left(0.2 \times 10^{6}\right.$ cells per well $)$ cells were grown in 
96-well culture plates using a RPMI-1640 medium supplemented with $10 \%$ FBS, 100 units/mL of penicillin, and $100 \mu \mathrm{g} / \mathrm{mL}$ of streptomycin. LPS $(50 \mathrm{ng} / \mathrm{mL})$ induced splenocyte cells cultures were grown for 48 hours at $37^{\circ} \mathrm{C}$ in a humidified $\mathrm{CO}_{2}$ incubator $\left(\begin{array}{lll}5 \% & \mathrm{CO}_{2}\end{array}\right)$. The effect of cytotoxicity from the formulation was tested by treating cells with different concentrations of the test formulation in RPMI-1640 medium. Various concentrations of the test formulation were used i.e. $0.00001053 \mu \mathrm{g} / \mathrm{mL}$ to 10.53 $\mu \mathrm{g} / \mathrm{mL}$ in the presence of inflammatory stimulus (LPS) for cell viability assay. The respective vehicle controls (DMSO) were kept in the assay for comparison.

\subsection{Cytotoxicity by MTT Assay}

The effects of the Biofield Treated and untreated test formulations on cell viability at the concentration range of $0.00001053 \mu \mathrm{g} / \mathrm{mL}$ to $10.53 \mu \mathrm{g} / \mathrm{mL}$ was tested using 3- $(4,5$ dimethythiazol-2-yl)-2, 5-diphenyl tetrazolium bromide (MTT) assay. The number of viable cells was determined by the ability of mitochondria to convert MTT to formazan dye. Splenocyte cells were cultured overnight in 96-well plates, at a density of $0.2 \times 10^{6}$ cells per well. After treatment with the test formulation and incubation period, the medium was removed. $20 \mu \mathrm{L}$ of $5 \mathrm{mg} / \mathrm{mL}$ MTT was then added to each well and incubated for 3 hours further at $37^{\circ} \mathrm{C}$ in a humidified 5\% $\mathrm{CO}_{2}$ atmosphere. The cells were centrifuged and supernatants were removed. The cell pellets in each well were resuspended in $150 \mu \mathrm{L}$ of DMSO to dissolve formazan crystals. The optical density of each well was read at $540 \mathrm{~nm}$ using a BioTek Reader (SIAFRT/Synergy HT multimode reader, US).

The effect of the test formulation on the cell viability of splenocyte cells was determined with equation (1):

$$
\% \text { Cell viability }=100-\% \text { cytotoxicity }
$$

Where; $\%$ cytotoxicity $=[(\mathrm{O} . \mathrm{D}$. of control cells $-\mathrm{O}$. D. of cells treated with the test formulation)/O. D. of control cells $]^{*} 100$.

The concentrations that resulted in $>75 \%$ viability were selected for subsequent cytokine estimation.

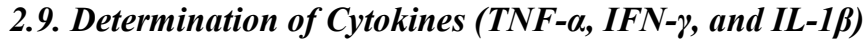 and Chemokine (MIP-1a) Using ELISA}

The in vitro activity of the Biofield Treated and untreated test formulations were estimated on the mice splenocyte cells for the production of TNF- $\alpha$, IFN- $\gamma$, MIP- $1 \alpha$, and IL- $1 \beta$ using enzyme-linked immunosorbent assay (ELISA). The ELISA plates were coated with an antibody in a coating buffer at the recommended concentration and kept overnight at $4^{\circ} \mathrm{C}$. After washing with PBS-T (PBS with $0.05 \%$ Tween 20), the plates were blocked with assay diluent for at least 2 hours at room temperature. A total of $100 \mu \mathrm{L}$ culture supernatant from different experimental samples and standards were incubated overnight at $4{ }^{\circ} \mathrm{C}$ and, after three washes, biotinylated antimice cytokine (TNF- $\alpha$, IFN- $\gamma$, MIP- $1 \alpha$, and IL- $1 \beta$ ) antibodies at the recommended concentrations were incubated for 1 hour at room temperature and the plates were incubated for 45 minutes at room temperature with gentle shaking. The plates were again washed 3 times and then $100 \mu \mathrm{L}$ of horseradish per-oxidase (HRP)-streptavidin conjugate solution was added and the plate was incubated for 45 minutes at room temperature with gentle shaking. Next, the plate wells were washed 3 times as previously done and 100 $\mu \mathrm{L}$ of 3,3,5,5'-tetramethylbenzidine (TMB) one-step substrate reagent was added, followed by a 30 -minute incubation at room temperature in the dark. Further, $50 \mu \mathrm{L}$ of 0.2 mole/L sulphuric acid was added to each well to stop the reaction and the plates were read for absorbance at $450 \mathrm{~nm}$ using a BioTek Reader (SIAFRT/Synergy HT multimode reader). Standards were run in parallel to the samples, and the concentrations were determined in triplicates for each sample [37].

\subsection{Statistical Analysis}

Data were expressed as mean \pm standard error of mean (SEM) and subjected to one-way analysis of variance (ANOVA) followed by Dunnett's test for multiple comparison and Student's $t$-test for two groups comparison. Statistical significance was considered at $p \leq 0.05$.

\section{Results}

\subsection{In vitro Splenocyte Cells Viability by MTT Assay}

In vitro splenocyte cells viability was performed after 48 hours using MTT assay, and the results are presented in Figure 1 with respect to the positive control, vehicle control, and the test formulation at different tested concentrations. The results showed a significant change in the percentage of cell viability in the tested concentrations of the test formulation after receiving the Biofield Energy Treatment. Con-A and rapamycin showed immunostimulatory and immunosuppressive action, respectively, and were used as the positive control in the experiment. The untreated cells, LPS, and Con-A group showed 100\%, 187.74\%, and 94.87\% cell viability, respectively. The vehicle control group reported with $100 \%$ and the rapamycin group as $136.85 \%, 132.28 \%$, $136.52 \%$, and $120.54 \%$ at concentrations $0.01,0.1,1$, and 10 $\mathrm{nM}$, respectively. With respect to the vehicle control, the percentage of cell viability was increased, which might be due to proliferation in the cell culture. The tested concentration range from 0.00001053 to $10.53 \mu \mathrm{g} / \mathrm{mL}$ of the herbomineral test formulation was selected for the splenocyte cells. The test formulation was found safe at all the tested concentrations, with percentage viability ranging from $77.50 \%$ to $176.52 \%$. The $\%$ cell viability of LPS alone at 0.5 $\mu \mathrm{g} / \mathrm{mL}$ was significantly increased by $87.74 \%$, while con-A decreased the cell viability at the same concentration as compared to the untreated cells. The percentage of cell viability was significantly increased by $10.09 \%, 8.90 \%$, and $10.30 \%$ at the concentrations $0.0001053,0.001053$, and $0.01053 \mu \mathrm{g} / \mathrm{mL}$, respectively in the Biofield Energy Treated test formulation as compared to the vehicle control (Figure 1). 


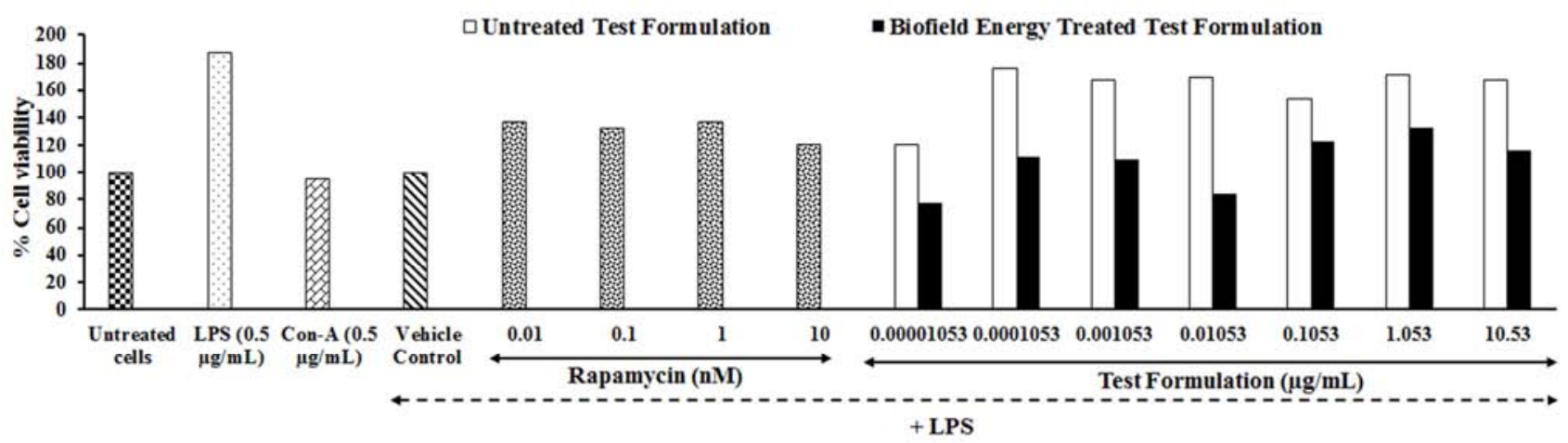

Figure 1. MTT assay in splenocyte cells after 48 hours of treatment with various concentrations of the test formulation in the presence of $0.5 \mu \mathrm{g} / \mathrm{mL}$ of LPS. The absorbance of the MTT formazan was determined at $540 \mathrm{~nm}$ in an ELISA reader. Cell viability was denoted as the absorbance ratio (expressed as a percentage) of the test formulation treated cells relative to the untreated vehicle cells. Values are represented as mean \pm SEM. RAP: Rapamycin; LPS: Lipopolysaccharide; Con-A: Concanavalin-A.

\subsection{Estimation of TNF- $\alpha$ Expression}

An estimation of TNF- $\alpha$ expression in splenocyte cells after treatment with the test formulation is represented in Figure 2. The level of TNF- $\alpha$ was $232.05 \%, 211.54 \%$, $262.50 \%$, and $229.81 \%$ in the positive control group (rapamycin) at $0.01,0.1,1$, and $10 \mu \mathrm{g} / \mathrm{mL}$, respectively. The expression of TNF- $\alpha$ was significantly reduced by $34.13 \%$, $32.34 \%, 20.83 \%, 17.76 \%, 30.46 \%, 10.52 \%$, and $15.68 \%$ at $0.00001053,0.0001053,0.001053,0.01053,0.1053,1.053$, and $10.53 \mu \mathrm{g} / \mathrm{mL}$, respectively in the untreated test formulation as compared to the VC. The Biofield Energy
Treated test formulation showed a significant reduction of TNF- $\alpha$ expression by $15.87 \%, 8.04 \%, 15.28 \%, 4.56 \%$, $12.30 \%, 12.60 \%$, and $22.72 \%$ at the concentrations $0.00001053,0.0001053,0.001053,0.01053,0.1053,1.053$, and $10.53 \mu \mathrm{g} / \mathrm{mL}$, respectively as compared to the vehicle control (VC). Further, the Biofield Energy Treated test formulation showed significant inhibition of TNF- $\alpha$ at 1.053 and $10.53 \mu \mathrm{g} / \mathrm{mL}$ by $2.33 \%$ and $8.35 \%$, respectively as compared to the untreated test formulation. The expression of TNF- $\alpha$ in the rest of the concentrations were also altered (Figure 2).

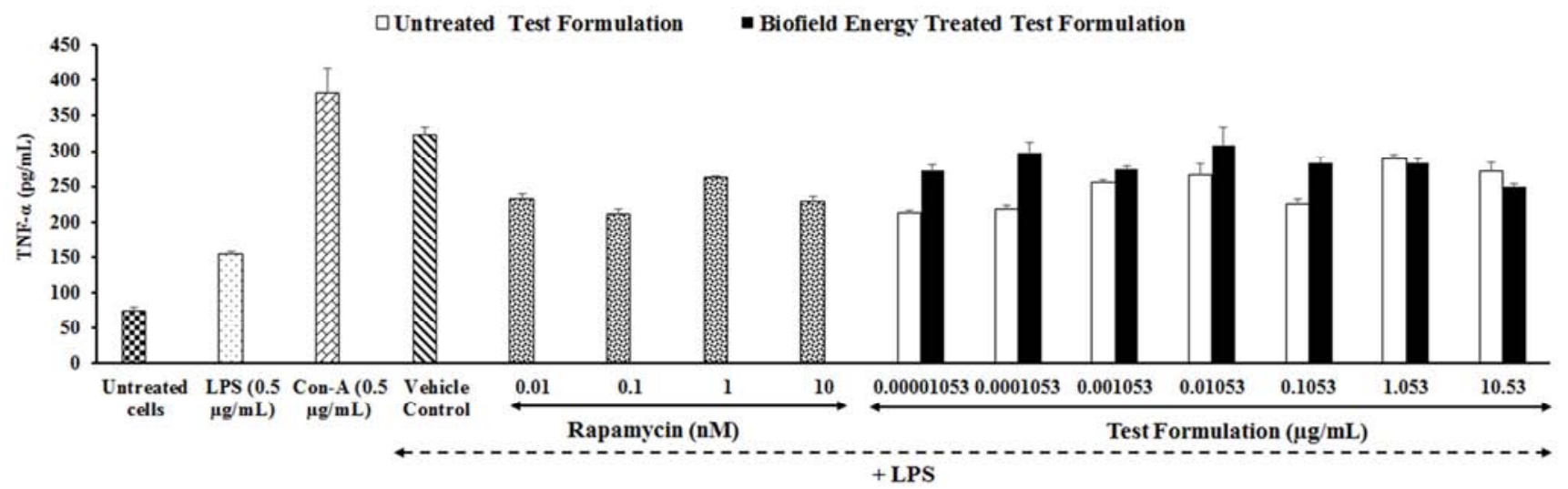

Figure 2. The effect of the test formulation on TNF- $\alpha$ secretion in LPS mediated splenocyte cells was measured after 48 hours of treatment. The values are represented as mean \pm SEM. RAP: Rapamycin; LPS: Lipopolysaccharide; Con-A: Concanavalin-A.

\subsection{Estimation of IL-1ß Expression}

The expression of IL-1 $\beta$ in mouse splenocytes in the presence of the test formulation is demonstrated in Figure 3. The positive control rapamycin showed up to $35.85 \pm 2.85$ $\mathrm{pg} / \mathrm{mL}$ of IL-1 $\beta$. The untreated test formulation showed significant reduction of IL- $1 \beta$ expression by $14.26 \%$, $24.61 \%, \quad 19.78 \%, \quad 18.17 \%, \quad 15.87 \%$, and $22.31 \%$ at $0.0001053,0.001053,0.01053,0.1053,1.053$ and 10.53 $\mu \mathrm{g} / \mathrm{mL}$, respectively as compared to the VC group. Moreover, the Biofield Energy Treated test formulation showed significant reduction of IL- $1 \beta$ secretion by $30.81 \%, 27.36 \%$,
$23.92 \%, \quad 18.40 \%, \quad 11.27 \%, \quad 21.16 \%, \quad$ and $7.14 \%$ at $0.00001053,0.0001053,0.001053,0.01053,0.1053,1.053$ and $10.53 \mu \mathrm{g} / \mathrm{mL}$, respectively as compared to the vehicle control. Both the Biofield Energy Treated and untreated test formulations demonstrated inhibition of IL-1 $\beta$ as compared to the LPS stimulated group. However, the Biofield Energy Treated test formulation exhibited better suppression than the untreated test formulation at $0.00001053,0.0001053$, and $1.053 \mu \mathrm{g} / \mathrm{mL}$ by $48.63 \%(p \leq 0.001), 15.28 \%$, and $6.28 \%$, respectively as compared to the untreated test formulation. This indicates that the Biofield Energy Healing enhanced the herbomineral test formulation's immunosuppressive property. 


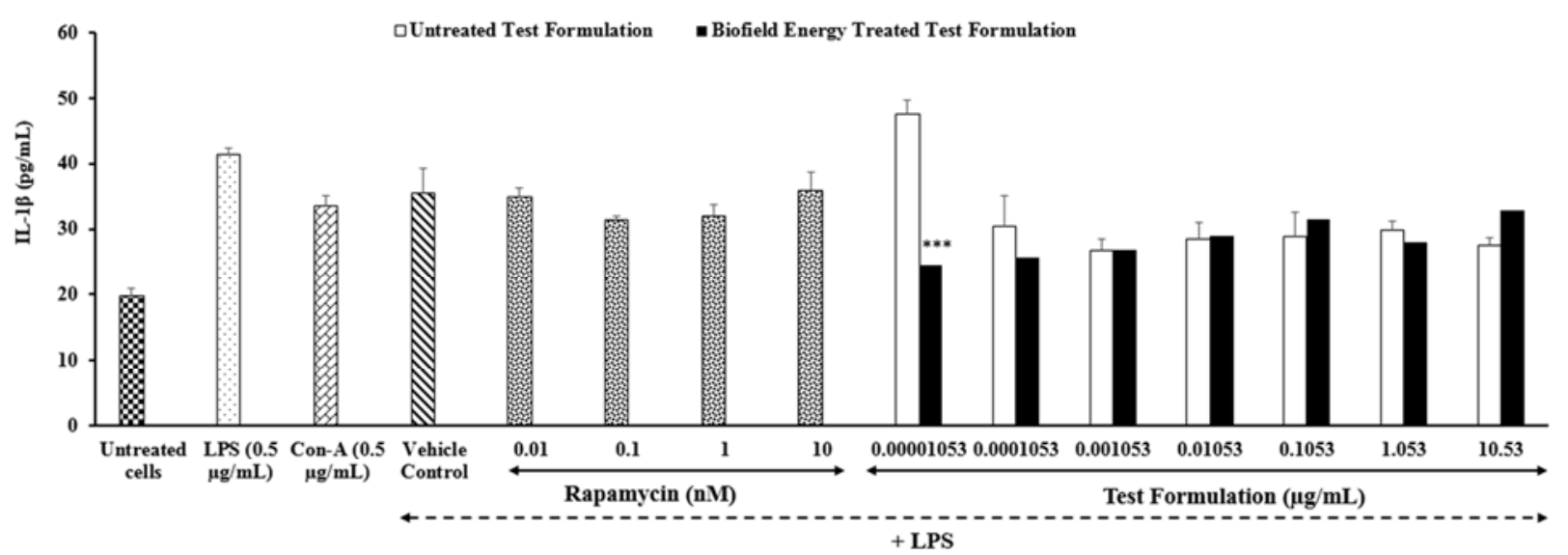

Figure 3. The effect of the test formulation on IL-1 $\beta$ secretion in LPS mediated splenocyte cells was measured after 48 hours of treatment. The values are represented as mean \pm SEM. RAP: Rapamycin; LPS: Lipopolysaccharide; Con-A: Concanavalin-A. ${ }^{* * *} p \leq 0.001$ vs. untreated test formulation.

\subsection{Estimation of MIP-1a Expression}

The effect of the Biofield Energy Treated test formulation on MIP-1 $\alpha$ secretion is shown in Figure 4. The results show the Biofield Energy Treated test formulation significantly reduced the the MIP- $1 \alpha$ expression by $5.25 \%, 22.33 \%$, $16.25 \%, 15.58 \%$, and $21.83 \%$ at $0.00001053,0.01053$, $0.1053,1.053$, and $10.53 \mu \mathrm{g} / \mathrm{mL}$, respectively as compared to the vehicle control. The expression of MIP- $1 \alpha$ was decreased by $25.57 \%, 24.81 \%, 1.43 \%, 10.45 \%, 11.34 \%, 10.79 \%$, and
$7.31 \%$ at $0.00001053,0.0001053,0.001053,0.01053$, $0.1053,1.053$ and $10.53 \mu \mathrm{g} / \mathrm{mL}$, respectively in the untreated test formulation as compared to the vehicle control. The data indicates that there was a significant down-regulation of MIP- $1 \alpha$ expression at $0.01053,0.1053,1.053$ and 10.53 $\mu \mathrm{g} / \mathrm{mL}$ by $13.27 \%, 5.54 \%, 5.36 \%$, and $15.67 \%\left({ }^{*} p<0.05\right)$, respectively in the Biofield Energy Treated test formulation as compared to the untreated test formulation (as shown in Figure 4).

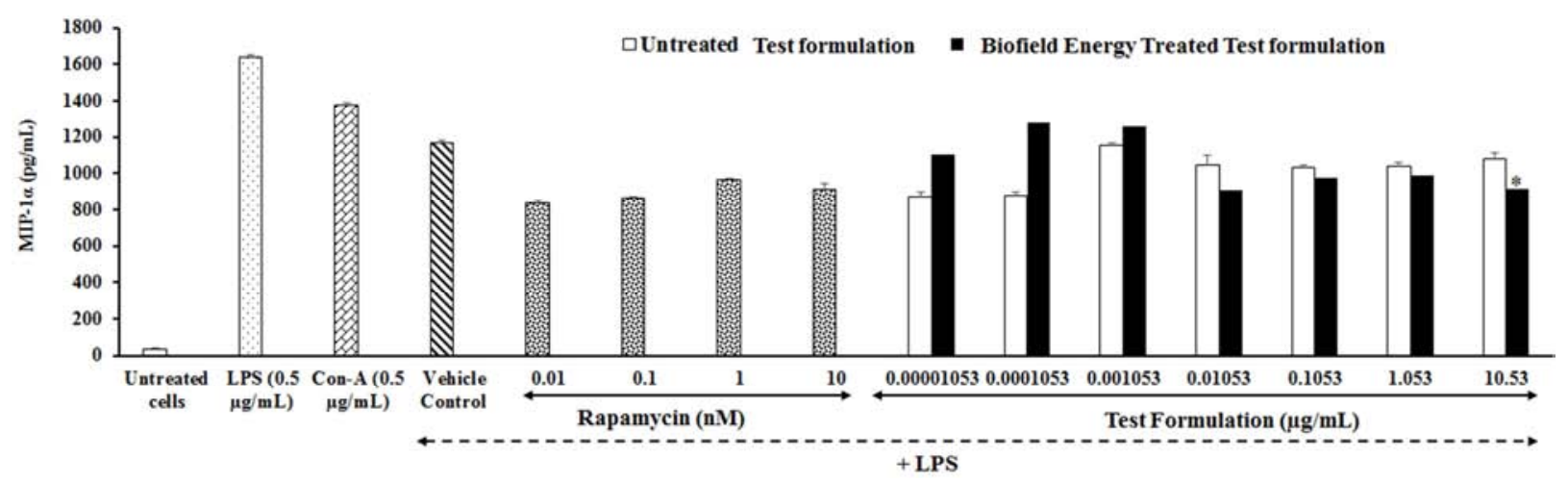

Figure 4. Concentration-dependent effect of LPS mediated production of MIP-1 $\alpha$ by the test formulation. For each concentration treatment, the level of MIP1a release was measured after 48 hours of treatment. The values are represented as mean $\pm S E M .{ }^{*}<0.05$ vs vehicle control. RAP: Rapamycin; LPS: Lipopolysaccharide; Con-A: Concanavalin-A.

\subsection{Estimation of IFN- $\gamma$ Expression}

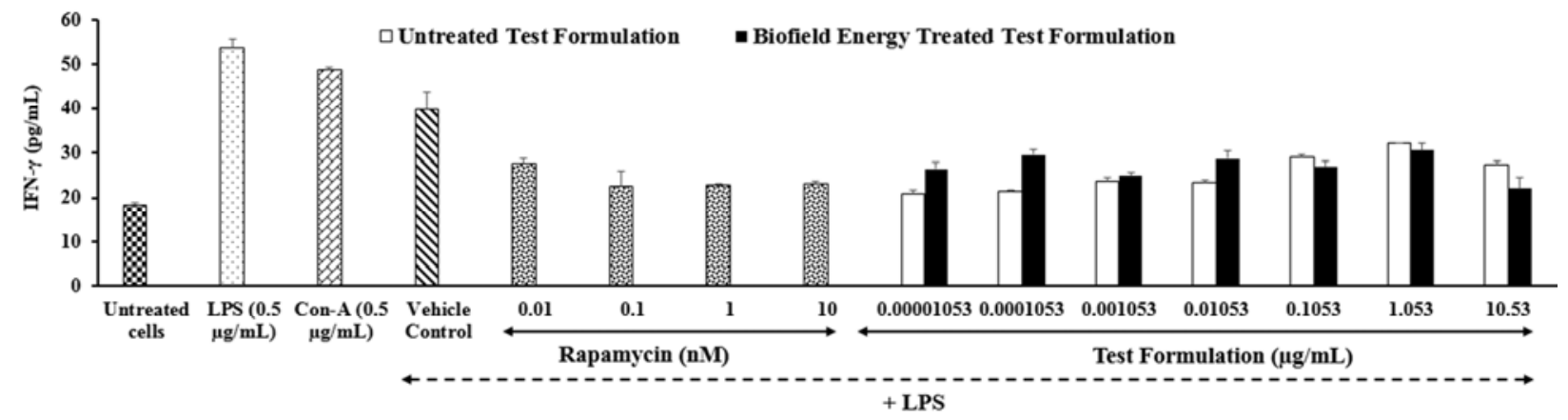

Figure 5. The effect of the test formulation on IFN- $\gamma$ secretion in LPS mediated splenocyte cells was measured after 48 hours of treatment. The values are represented as mean \pm SEM. RAP: Rapamycin; LPS: Lipopolysaccharide; Con-A: Concanavalin-A. 
The estimation of IFN- $\gamma$ expression in splenocyte cells after treatment with the Biofield Energy Treated and untreated test formulations is represented in Figure 5. The expression of IFN- $\gamma$ was decreased by $47.06 \%, 45.72 \%$, $40.34 \%, \quad 40.68 \%, \quad 26.90 \%, \quad 18.83 \%$, and $31.10 \%$ at $0.00001053,0.0001053,0.001053,0.01053,0.1053,1.053$ and $10.53 \mu \mathrm{g} / \mathrm{mL}$, respectively in the untreated test formulation as compared to the vehicle control. The Biofield Energy Treated test formulation showed significant inhibition of IFN- $\gamma$ expression by $33.45 \%, 25.38 \%, 37.15 \%, 27.74 \%$, $32.44 \%, 23.03 \%$, and $44.21 \%$ at $0.00001053,0.0001053$, $0.001053,0.01053,0.1053,1.053$, and $10.53 \mu \mathrm{g} / \mathrm{mL}$, respectively as compared to the vehicle control. The data indicated that there was a significant down-regulation of IFN- $\gamma$ expression at $0.1053,1.053$, and $10.53 \mu \mathrm{g} / \mathrm{mL}$ by $7.59 \%, 5.18 \%$, and $19.02 \%$, respectively in the Biofield Energy Treated test formulation as compared to the untreated test formulation group (demonstrated in Figure 5).

\section{Discussion}

The novel proprietary herbomineral formulation was designed, consisting of a combination of ashwagandha and the minerals zinc chloride, magnesium gluconate hydrate, and sodium selenate. Each of the individual components of this formulation has been proven to have immunomodulatory activities. Ashwagandha has been shown to inhibit TNF- $\alpha$ induced nuclear factor-kappa $\mathrm{B}(N F-\kappa B)$ activation in human myelomonoblastic leukemia cells in a study conducted by Singh and Aggrawal (2007) [38]. Selenium is an essential trace element that plays an important role in protecting cells from oxidative stress. As a supplementation to the diet, selenium may reduce the risk of cardiomyopathy, cancer, and immune disorders in humans [39, 40]. Zinc deficiency influences the generation of cytokines, including IL-1 $\beta$, IL-2, IL-6, and TNF- $\alpha$. In response to zinc supplementation, plasma cytokines exhibit a dose-dependent response. The mechanism of action may reflect the ability of zinc to induce or inhibit the activation of $N F-\kappa B$. The wide involvement of zinc in the immune system [41] includes an ability to influence the production and signaling of numerous inflammatory cytokines in a variety of cell types [42]. Magnesium sulfate reduced cytokine production in intrapartum women and term and preterm neonates, demonstrating effectiveness in those at risk for inflammation associated adverse perinatal outcomes, whereby magnesium plays a critical regulatory role in $N F-\kappa B$ activation, cytokine production, and disease pathogenesis [43]. TNF- $\alpha$ is a circulating factor and is also identified as a key regulator of the inflammatory response. Literature evidenced that it can interact with two different types of receptors, tumor necrosis factor receptor 1 and 2 (TNFR1 and TNFR2), which are differentially expressed in cells and tissues and initiate both distinct and overlapping signal transduction pathways. These diverse signaling cascades lead to a range of cellular responses, which include cell death, survival, differentiation, proliferation and migration [44]. In this experiment, the expression of TNF- $\alpha$ was further inhibited in the Biofield Energy Treated test formulation at five concentrations as compared to the vehicle control, and two concentrations as compared to the untreated test formulation group. Thus, it is assumed that the down-regulation of cellular response might be accelerated due to the Biofield Energy Healing administered to the Biofield Treated test formulation.

The IL- $1 \beta$ is a pro-inflammatory cytokine that has been implicated in pain, inflammation, and autoimmune conditions. The level of IL- $1 \beta$ expression was significantly inhibited at two concentrations $(0.00001053$ and 0.0001053 $\mu \mathrm{g} / \mathrm{mL})$ in the Biofield Energy Treated test formulation as compared to the untreated test formulation. It has been reported that the decreased production of IL-1 $\beta$ is helpful in the reduction of inflammation [45]. MIP- $1 \alpha$ is a member of the chemokines, and has been shown to contribute to monocyte/macrophage and neutrophil chemotaxis and activation. The expression of MIP-1 alpha mRNA in macrophages is induced by a variety of stimuli [46]. It was also observed that the level of MIP- $1 \alpha$ expression was significantly inhibited in the Biofield Energy Treated test formulation as compared to the untreated test formulation. This decreased production of MIP- $1 \alpha$ in the Biofield Energy Treated test formulation might be due to the down-regulation of MIP-1 $\alpha$ mRNA expression and protein synthesis via the generation of reactive oxygen species (ROS). Additionally, the decrease in MIP-1 alpha mRNA levels might be due to transcriptional inactivation and post-transcriptional destabilization [47]. IFN- $\gamma$ is an extraordinarily pleotropic cytokine. It acts in both the innate and adaptive immune responses against pathogens and tumors, and also has the ability to maintain immune homeostasis [48]. The IFN- $\gamma$ expression was significantly inhibited at $10.53 \mu \mathrm{g} / \mathrm{mL}$ in the Biofield Energy Treated test formulation as compared to the untreated test formulation. This decreased production of IFN$\gamma$ in the Biofield Energy Treated test formulation might be due to the suppression of inflammatory molecules, alteration of apoptotic mediators, and the downregulation and nuclear translocation of STAT1 [49].

Inflammation is the first response of the immune system to infection or irritation. It is caused by cytokines such as TNF$\alpha$, IL-1, and IL- 6 by eicosanoids such as prostaglandin E2 (PGE2) [50]. Thus, inhibitors of these cytokines have been sought after as anti-inflammatory drugs. Biofield Therapies (such as Reiki, therapeutic touch, healing touch and other types of Energy Medicine) are complementary and alternative medicine modalities that are often utilized by a significant number of cancer patients. These therapies show strong evidence in reducing pain intensity in those suffering from chronic pain, and moderate evidence in reducing pain intensity in cancer populations [51, 52]. The Biofield Energy Treated test formulation strongly inhibited the proinflammatory cytokines TNF- $\alpha$, MIP- $1 \alpha$, IFN- $\gamma$, and IL- $1 \beta$. Therefore, these results suggest that the Biofield Energy Treated test formulation may inhibit the inflammatory 
response of splenocytes by modulating the signal transduction pathways.

\section{Conclusions}

Cell viability was assessed using MTT assay and the herbomineral formulation was found to be safe at all the tested concentrations. The level of TNF- $\alpha$ was significantly decreased by $8.35 \%$ at $10.53 \mu \mathrm{g} / \mathrm{mL}$ in the Biofield Energy Treated test formulation as compared to the untreated test formulation. Moreover, the level of IL- $1 \beta$ was significantly reduced by $48.63 \%(p \leq 0.001)$ and $15.28 \%$ at 0.00001053 and $0.0001053 \mu \mathrm{g} / \mathrm{mL}$, respectively in the Biofield Energy Treated test formulation as compared to the untreated test formulation. In addition, expression of MIP-1 $\alpha$ was significantly reduced by $13.27 \%$ and $15.67 \%(p<0.05)$ at 0.01053 and $10.53 \mu \mathrm{g} / \mathrm{mL}$, respectively in the Biofield Energy Treated test formulation as compared to the untreated test formulation. Furthermore, the Biofield Energy Treated test formulation showed $19.02 \%$ downregulation of IFN- $\gamma$ expression at $10.53 \mu \mathrm{g} / \mathrm{mL}$ as compared to the untreated test formulation.

Overall, The Trivedi Effect ${ }^{\circledR}$ - Biofield Energy Healing (TEBEH) administered remotely by the twenty Biofield Energy Healers to the test formulation significantly inhibited the activity of pro-inflammatory cytokines and showed immunosuppressive activity with a safe therapeutic index as compared with the untreated test formulation. Biofield Energy Healing shows great promise as a Complementary and Alternative Medicine (CAM) therapy and might play an important role in treating autoimmune diseases and inflammatory disorders like Lupus, Systemic Lupus Erythematosus, Hashimoto Thyroiditis, Type 1 Diabetes, Asthma, Chronic peptic ulcers, Tuberculosis, Hepatitis, Chronic active hepatitis, Celiac Disease (glutensensitive enteropathy), Addison Disease, Crohn's disease, Graves' Disease, Pernicious and Aplastic Anemia, Sjogren Syndrome, Irritable Bowel Syndrome (IBS), Multiple Sclerosis, Rheumatoid arthritis, Chronic periodontitis, Ulcerative colitis, Chronic sinusitis, Myasthenia Gravis, Atherosclerosis, Vasculitis, Dermatitis, Diverticulitis, Rheumatoid Arthritis, Reactive Arthritis, Alopecia Areata, Psoriasis, Scleroderma, Fibromyalgia, Chronic Fatigue Syndrome, Vitiligo, Parkinson's Disease, Alzheimer's Disease, and stress etc. Biofield Energy Healing may also be useful in the prevention of immune-mediated tissue damage in cases of organ transplants (such as liver transplants, kidney transplants and heart transplants), as well as for anti-aging and improving overall health and quality of life.

\section{Abbreviations}

LPS: Lipopolysaccharide; DMSO: Dimethyl sulfoxide; FBS: Fetal bovine serum; MTT: 3-(4,5-Dimethylthiazol-2yl)-2,5-diphenyltetrazolium bromide; PBS: Phosphate buffer saline; ELISA: Enzyme-linked immunosorbent assay

\section{Acknowledgements}

The authors are grateful to Dabur Research Foundation, Trivedi Science, Trivedi Global, Inc. and Trivedi Master Wellness for their assistance and support during this work.

\section{References}

[1] Thomson GE (2007) The Health Benefits of Traditional Chinese Plant Medicines: Weighing the Scientific Evidence: A Report for the Rural Industries Research and Development Corporation, RIRDC, Barton, Australia.

[2] Rishton GM (2008) Natural products as a robust source of new drugs and drug leads: Past successes and present day issues. Am J Cardiol 101: 43D-49D.

[3] Darien BJ, Godbee RJ (2009) Morinda citrifolia based formulations for regulating $\mathrm{T}$ cell immunomodulation in neonatal stock animals. USA Patent 20090068204.

[4] Ziauddin M, Phansalkar N, Patki P, Diwanay S, Patwardhan B (1996) Studies on the immunomodulatory effects of ashwagandha. J Ethnopharmacol 50: 69-76.

[5] Lukác N, Massányi P (2007) Effects of trace elements on the immune system. Epidemiol Mikrobiol Imunol 56: 3-9.

[6] Galland L (1998) Magnesium and immune function: An overview. Magnesium 7: 290-299.

[7] Wintergerst ES, Maggini S, Hornig DH (2007) Contribution of selected vitamins and trace elements to immune function. Ann Nutr Metab 51: 301-323.

[8] Girdhari L, Rana A (2007) Withania somnifera (Ashwagandha): A review. Pharmacogn Rev 1: 129-136.

[9] Owais M, Sharad KS, Shehbaz A, Saleemuddin M (2005) Antibacterial efficacy of Withania somnifera (Ashwagandha) an indigenous medicinal plant against experimental murine salmonellosis. Phytomedicine 12: 229-235.

[10] Singh N, Bhalla M, de Jager P, Gilca M (2011) An overview on ashwagandha: A Rasayana (Rejuvenator) of Ayurveda. Afr J Tradit Complement Altern Med 8: 208-213.

[11] Mazumder PM, Pattnayak S, Parvani H, Sasmal D, Rathinavelusamy P (2012) Evaluation of immunomodulatory activity of Glycyrhiza glabra L roots in combination with zing. Asian Pac J Trop Biomed 2: S15-S20.

[12] Lutgendorf SK, Mullen-Houser E, Russell D, Degeest K, Jacobson G, Hart L, Bender D, Anderson B, Buekers TE, Goodheart MJ, Antoni MH, Sood AK, Lubaroff DM (2010) Preservation of immune function in cervical cancer patients during chemoradiation using a novel integrative approach. Brain Behav Immun 24: 1231-1240.

[13] Ironson G, Field T, Scafidi F (1996) Massage therapy is associated with enhancement of the immune system's cytotoxic capacity. Int J Neurosci 84: 205-217.

[14] Jain S, Hammerschlag R, Mills P, Cohen L, Krieger R, Vieten C, Lutgendorf S (2015) Clinical studies of biofield therapies: Summary, methodological challenges, and recommendations. Glob Adv Health Med 4: 58-66. 
[15] Rubik B (2002) The biofield hypothesis: Its biophysical basis and role in medicine. J Altern Complement Med 8: 703-717.

[16] Trivedi MK, Patil S, Shettigar H, Mondal SC, Jana S (2015) The potential impact of biofield treatment on human brain tumor cells: A time-lapse video microscopy. J Integr Oncol 4: 141 .

[17] Trivedi MK, Patil S, Shettigar H, Gangwar M, Jana S (2015) In vitro evaluation of biofield treatment on cancer biomarkers involved in endometrial and prostate cancer cell lines. J Cancer Sci Ther 7: 253-257.

[18] Trivedi MK, Patil S, Shettigar H, Mondal SC, Jana S (2015) In vitro evaluation of biofield treatment on Enterobacter cloacae: Impact on antimicrobial susceptibility and biotype. J Bacteriol Parasitol 6: 241.

[19] Trivedi MK, Patil S, Shettigar H, Mondal SC, Jana S (2015) Evaluation of biofield modality on viral load of hepatitis B and C Viruses. J Antivir Antiretrovir 7: 083-088.

[20] Trivedi MK, Patil S, Shettigar H, Mondal SC, Jana S (2015) An impact of biofield treatment: Antimycobacterial susceptibility potential using BACTEC 460/MGIT-TB System. Mycobact Dis 5: 189.

[21] Trivedi MK, Branton A, Trivedi D, Nayak G, Mondal SC, Jana S (2015) Antimicrobial sensitivity, biochemical characteristics and biotyping of Staphylococcus saprophyticus: An impact of biofield energy treatment. J Women's Health Care 4: 271.

[22] Trivedi MK, Branton A, Trivedi D, Nayak G, Mondal SC, Jana S (2015) Evaluation of antibiogram, genotype and phylogenetic analysis of biofield treated Nocardia otitidis. Biol Syst Open Access 4: 143.

[23] Trivedi MK, Branton A, Trivedi D, Nayak G, Charan S, Jana S (2015) Phenotyping and 16S rDNA analysis after biofield treatment on Citrobacter braakii: A urinary pathogen. J Clin Med Genom 3: 129.

[24] Trivedi MK, Patil S, Shettigar H, Bairwa K, Jana S (2015) Spectroscopic characterization of chloramphenicol and tetracycline: An impact of biofield. Pharm Anal Acta 6: 395.

[25] Trivedi MK, Patil S, Shettigar H, Bairwa K, Jana S (2015) Spectroscopic characterization of biofield treated metronidazole and tinidazole. Med Chem 5: 340-344.

[26] Trivedi MK, Patil S, Shettigar H, Bairwa K, Jana S (2015) Effect of biofield treatment on spectral properties of paracetamol and piroxicam. Chem Sci J 6: 98.

[27] Trivedi MK, Branton A, Trivedi D, Shettigar H, Bairwa K, Jana S (2015) Fourier transform infrared and ultravioletvisible spectroscopic characterization of biofield treated salicylic acid and sparfloxacin. Nat Prod Chem Res 3: 186.

[28] Trivedi MK, Branton A, Trivedi D, Nayak G, Gangwar M, Jana S (2016) Molecular analysis of biofield treated eggplant and watermelon crops. Adv Crop Sci Tech 4: 208.

[29] Trivedi MK, Branton A, Trivedi D, Nayak G, Mondal SC, Jana S (2015) Morphological characterization, quality, yield and DNA fingerprinting of biofield energy treated alphonso mango (Mangifera indica L.). Journal of Food and Nutrition Sciences 3: 245-250.

[30] Trivedi MK, Branton A, Trivedi D, Nayak G, Mondal SC,
Jana S (2015) Evaluation of plant growth, yield and yield attributes of biofield energy treated mustard (Brassica juncea) and chick pea (Cicer arietinum) seeds. Agriculture, Forestry and Fisheries 4: 291-295.

[31] Trivedi MK, Branton A, Trivedi D, Nayak G, Mondal SC, Jana S (2015) Evaluation of plant growth regulator, immunity and DNA fingerprinting of biofield energy treated mustard seeds (Brassica juncea). Agriculture, Forestry and Fisheries 4: 269-274.

[32] Trivedi MK, Tallapragada RM, Branton A, Trivedi D, Nayak G, Jana S (2015) Characterization of physical and structural properties of aluminum carbide powder: Impact of biofield treatment. J Aeronaut Aerospace Eng 4: 142.

[33] Trivedi MK, Nayak G, Patil S, Tallapragada RM, Latiyal O, Jana $S$ (2015) Impact of biofield treatment on atomic and structural characteristics of barium titanate powder. Ind Eng Manage 4: 166.

[34] Trivedi MK, Patil S, Nayak G, Jana S, Latiyal O (2015) Influence of biofield treatment on physical, structural and spectral properties of boron nitride. J Material Sci Eng 4: 181.

[35] Trivedi MK, Nayak G, Patil S, Tallapragada RM, Latiyal O, Jana S (2015) Characterization of physical and structural properties of brass powder after biofield treatment. J Powder Metall Min 4: 134.

[36] Wu QL, Fu YF, Zhou WL, Wang JX, Feng YH, Liu J, Xu JY, He PL, Zhou R, Tang W, Wang GF, Zhou Y, Yang YF, Ding J, Li XY, Chen XR, Yuan C, Lawson BR, Zuo JP (2005) Inhibition of S-adenosyl-1-homocysteine hydrolase induces immunosuppression. J Pharmacol Exp Ther 313: 705-711.

[37] Madaan A, Kanjilal S, Gupta A, Sastry JL, Verma R, Singh AT, Jaggi M (2015) Evaluation of immunostimulatory activity of Chyawanprash using in vitro assays. Indian J Exp Biol 53: 158-163.

[38] Singh D, Aggarwal A, Maurya R, Naik S (2007) Withania somnifera inhibits NF- $\mathrm{BB}$ and $\mathrm{AP}-1$ transcription factors in human peripheral blood and synovial fluid mononuclear cells. Phytother Res 21: 905-913.

[39] Rayman MP (2000) The importance of selenium to human health. Lancet 356: 233-241.

[40] Ren F, Chen X, Hesketh J, Gan F, Huang K (2012) Selenium promotes T-cell response to TCR-stimulation and ConA, but not PHA in primary porcine splenocytes. PLoS One 7: e35375.

[41] Kruse-Jarres JD (1989) The significance of zinc for humoral and cellular immunity. J Trace Elem Electrolytes Health Dis 3: $1-8$.

[42] Abbas AK, Lichtman AH (2005) Cellular and Molecular Immunology, $5^{\text {th }}$ ed.; Elsevier Saunders: Philadelphia, PA, USA.

[43] Sugimoto J, Romani AM, Valentin-Torres AM, Luciano AA, Ramirez Kitchen CM (2012) Magnesium decreases inflammatory cytokine production: A novel innate immunomodulatory mechanism. J Immunol 188.

[44] Bradley JR (2008) TNF-mediated inflammatory disease. J Pathol 214: 149-160.

[45] Jesus AA, Goldbach-Mansky R (2014) IL-1 blockade in autoinflammatory syndromes. Annu Rev Med 65: 223-244. 
[46] Haeberle HA, Kuziel WA, Dieterich HJ, Casola A, Gatalica Z, Garofalo RP (2001) Inducible expression of inflammatory chemokines in respiratory syncytial virus-infected mice: Role of MIP-1alpha in lung pathology. J Virol 75: 878-890.

[47] Chong IW, Lin SR, Hwang JJ, Huang MS, Wang TH, Hung JY, Paulauskis JD (2002) Expression and regulation of the macrophage inflammatory protein-1 alpha gene by nicotine in rat alveolar macrophages. Eur Cytokine Netw 13: 242-249.

[48] Lin FC, Young HA (2013) The talented interferon-gamma. Advances in Bioscience and Biotechnology 4: 6-13.

[49] De Saint Jean M, Brignole F, Feldmann G, Goguel A, Baudouin C (1999) Interferon-gamma induces apoptosis and expression of inflammation-related proteins in Chang conjunctival cells. Invest Ophthalmol Vis Sci 40: 2199-2212.

[50] Ricciotti E, FitzGerald GA (2011) Prostaglandins and inflammation. Arterioscler Thromb Vasc Biol 31: 986-1000.

[51] Jain S, Mills PJ (2010) Biofield therapies: Helpful or full of hype? A best evidence synthesis. Int J Behav Med 17: 1-16.

[52] Warber SL, Cornelio D, Straughn J, Kile G (2004) Biofield energy healing from the inside. J Altern Complement Med 10: 1107-1113. 